\title{
HUBUNGAN MOTIVASI BIDAN TENTANG P4K DENGAN PENERAPAN PROGRAM STIKER P4K PADA IBU HAMIL DI RUMAH SAKIT IMELDA MEDAN
}

\author{
Khairani \\ Universitas Imelda Medan, Indonesia
}

\begin{tabular}{l}
\hline Article Info \\
\hline Article history: \\
Received Feb 27, 2021 \\
Revised Mar 04, 2021 \\
Accepted Mar 13, 2021 \\
\hline
\end{tabular}

\section{Keywords:}

Motivation

Implementation

Sticker

PCPP

\begin{abstract}
Maternal Mortality Rate (MMR) and Infant Mortality Rate (IMR) are health indicators of a country. Data of the 2012 Demographic Health Survey of Indonesia (DHSI) indicates that the maternal mortality rate increased by 359 deaths per 100.000 live births. Such rate was higher than the data of 2015 DHSI, i.e. 228 deaths per 100.000 live births. The 2012 DHSI indicates IMR of 32 deaths per 1.000 live births, slightly lower than the 2007 DHSI indicating 34 deaths per 1.000 live births. This research is aimed at identifying the correlation between midwives' motivation about the Delivery Planning and Complication Prevention Program (PCPP) and the implementation of PCPP sticker for pregnant women in the Imleda Hospital. This research belonged to a descriptive quantitative analytic research with cross sectional approach. Data were collected using accidental sampling with the research subjects involving 63 midwives in the Imelda Hospital. Midwives' motivation about PCPP belonged to the category of moderate motivation (79.4\%). The implementation of PCPP sticker program was mostly as planned $(74.6 \%)$. There was a correlation between midwives' motivation about PCPP and the implementation of PCPP sticker for pregnant women in the Imelda Hospital in 2020 with $\mathrm{p}$-value $=0.013$.
\end{abstract}

This is an open access article under the CC BY-SAlicense.

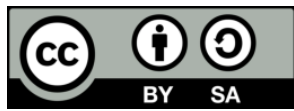

Corresponding Author:

Khairani,

Program Studi DIII Perekam Dan Informasi Kesehatan,

Universitas Imelda Medan,

Jl. Bilal No. 52 Kelurahan Pulo Brayan Darat I Kecamatan Medan Timur, Medan - Sumatera Utara.

Email: khairanizaharah@gmail.com

\section{INTRODUCTION}

Pembangunan kesehatan bertujuan untuk meningkatkan kesadaran, kemauan serta kemampuas untuk hidup lebih sehat oleh setiap orang sehingga meningkatkan terwjudnya derajat kesehatan yang maksimal. Penyelenggaraan pembangunan kesehatan harus didasarkan pada perikemanusiaan, pemberdayaan dan kemandirian serta adil dan merata disertai perhatian yang khusus bagi penduduk yang rentan seperti ibu, bayi, anak, lanjut usia serta orang miskin.

Angka Kematian Ibu (AKI) dan Angka Kematian Bayi (AKB) sebagai salah satu indikator derajat kesehatan setiap Negara. Data terlihat bahwa angkat kematian ibu mengalami peningkatan yaitu 359 per 100.000 kelahiran hidup. Angka tersebut merupakan tertinggi bila disandingkan dengan Negara-Negara 
ASEAN lainnya Antara lain seperti Malaysia 62/100.000 kelahiran hidup (KH), Srilanka 58/100.000 KH dan Philipina 230/100.000 KH.

Nilai AKB di Indonesia belum mendekati target MDG's (Millenium Development Goals) yaitu AKB tahun 2015 sebesar 23/1.000 KH. Berdasarkan Data Dinas Kesehatan Kota Medan Sumatera Utara dilaporakan bahwa angka AKI sebesar 32/1000 KH dan AKB sebesar 20/1000KH sedikit lebih rendah bila dibandingkan dengan SDKI tahun 2015 yaitu 34/1000 KH.

Untuk menurunkan percepatan angka AKI diperlukan 4 buah strategi penting Antara lain, peningkatan dan akses pelayanan kesehatan ibu dan anak, Kerjasama lintas program, sektor swasta dan masyarakat, peberdayaan wanita, keluarga dan masyarakat serta meningkatkan pengawasan dan mengevaluasi KIA dan Pembiyaan Menteri Kesehatan pada Tahun 2015 menggagaskan suatu program (P4K) Program Perencanaan Persalinan an Pencegahan Komplikasi (P4K) dalam bentuk gambar-gambar sebagai upaya terobosan untuk mendorong percepatan penuruanan AKI dan BBL dengan cara membuat kegiatan yang dapat membangun potensi masyarakat yang mengarah kepada kepedulian masyarakat dalam mempersiapkan asas tindakan menyelamatkan ibu dan bayi baru lahir. Berdasarkan uraian tersebut di atas, maka peneliti tertarik untuk meneliti tentang hubungan motivasi bidan tentang P4K dengan Penerapan Stiker P4K pada Ibu Hamil di Rumah Sakit Imelda Medan Tahun 2020.

\section{RESEARCH METHOD}

Metode penelitian ini merupakan penelitian deskriptif kuantitatif analitik dengan desain penelitian cross sectional. Kegiatan penelitian dilakukan di Rumah Sakit Imelda Medan teknik sampel dalam penelitian ini menggunakan metode accidental sampling dan sebagai sampel dalam penelitian ini adalah bidan-bidan yang bekerja di lingkungan Rumah Sakit Imleda Medan sebanyak 63 orang. Variabel dalam penelitian ini yaitu variabel independen yaitu motivasi bidan tentang P4K dan variabel dependent yaitu penerapan program stiker P4K pada ibu hamil. Definisi operasional yaitu kemampuan responden dalam menjawab dengan benar atas kuesioner tentang motivasi bidan tentang program P4K dan Penempelan stiker P4K pada ibu hamil.

Cara pengumpulan data untuk memperoleh data mengenai motivasi bidan tentang program $\mathrm{P} 4 \mathrm{~K}$ menggunakan jawaban tertutup terdiri dari 24 item soal. Pengolahan dan analisis data dilakukan dengan editing, coding skoring, tabulating, entring. Kemudian dilanjutkan dengan analisa univariat dan bivariat untuk mendapatkan hubungan distribusi proporsi.

\section{RESULTS AND ANALYSIS}

\subsection{Results}

\section{Analisis Univariat}

Berdasarkan penelitian yang dilakukan terhadap 63 orang responden tentang judul "Hubungan Motivasi Bidan Tentang P4K Dengan Penerapan Program Stiker P4K Pada Ibu Hamil Di Rumah Sakit Imelda Medan" maka di dapat hasil sebagai berikut:

Tabel 1. Distribusi Karakteristik Responden

\begin{tabular}{|c|c|c|}
\hline Karakteristik & Frekuensi & Persentase (\%) \\
\hline \multicolumn{3}{|l|}{ Umur } \\
\hline 17-25 tahun & 4 & 6,3 \\
\hline 26-45 tahun & 45 & 71,4 \\
\hline $46-55$ tahun & 14 & 22,3 \\
\hline Jumlah & 63 & 100 \\
\hline \multicolumn{3}{|l|}{ Pendidikan terakhir } \\
\hline Diploma I & 4 & 6,3 \\
\hline Diploma III & 51 & 81,0 \\
\hline Diploma IV & 8 & 12,7 \\
\hline Jumlah & 63 & 100 \\
\hline \multicolumn{3}{|l|}{ Status kepegawaian } \\
\hline Pegawai Negeri Sipil (PNS) & - & - \\
\hline Pegawai Tetap (PTT) & 47 & 74,6 \\
\hline Pegawai Honorer & 16 & 25,4 \\
\hline Jumlah & 63 & 100 \\
\hline
\end{tabular}

Berdasarkan penelitian pada tabel 1menunjukan bahwa sebagian besar responden memiliki usia 2645 tahun sebanyak 45 orang $(71,4 \%)$ minoritas umur responden $17-25$ tahun sebanyak 4 orang $(6,3 \%)$. Mayoritas responden memiliki pendidikan terakhir Diploma III sebanyak 51 orang (81,0\%), minoritas 
responden memiliki pendidikan terakhir sebanyak 8 orang $(12,7 \%)$. Dan mayoritas status kepegawaian di Rumah Sakit Imelda Medan yaitu Pegawai tetap sebanyak 47 orang (74,6\%).

Tabel 2. Distribusi Frekuensi Motivasi Bidan

\begin{tabular}{cccc}
\hline No. & Tingkat Pengetahuan & Frekuensi (f) & Presentase (\%) \\
\hline 1 & Rendah & 6 & 9,5 \\
\hline 2 & Sedang & 50 & 79,4 \\
\hline 3 & Tinggi & 7 & 11,1 \\
\hline & Total & $\mathbf{6 3}$ & $\mathbf{1 0 0}$
\end{tabular}

Dari tabel 2 dapat diketahui bahwa mayoritas responden memiliki motivasi sedang sebanyak 50 orang $(79,4 \%)$ dan minoritas responden memiliki motivasi rendah sebanyak 6 orang $(9,5 \%)$.

Tabel 3. Distribusi Frekuensi Penerapan Program Stiker P4K

\begin{tabular}{lcc}
\hline \multicolumn{1}{c}{ Penerapan Stiker P4K } & Frekuensi & Persentase \\
\hline Sesuai & 17 & 27,0 \\
\hline Tidak sesuai & 46 & 73,0 \\
\hline Jumlah & $\mathbf{6 3}$ & $\mathbf{1 0 0}$
\end{tabular}

Berdasarkan tabel 3 di atas dapat di lihat bahwa mayoritas penerapan program stiker P4K adalah tidak sesuai sebanyak 46 orang $(73,0 \%)$.

\section{Analisa Bivariat}

Analisis bivariat menggunakan uji chi square, dimana uji chi square harus memenuhi syarat tabel $2 \times 2$ dan nilai cell tidak lebih dari $20 \%$. Pada penelitian ini dengan jenis tabel $3 \times 2$ sehingga dilakukan penggabungan tabel pada variabel motivasi bidan yang sebelumnya rendah, sedang dan tinggi dirubah menjadi rendah (rendah-sedang) dan tinggi seperti pada tabel berikut:

Tabel 4. Hubungan Motivasi Bidan Tentang P4K dengan Penerapan Program Stiker P4K

\begin{tabular}{|c|c|c|c|c|c|c|c|c|}
\hline \multirow{3}{*}{ Motivasi } & \multicolumn{4}{|c|}{ Penerapan Stiker P4K } & \multirow{2}{*}{\multicolumn{2}{|c|}{ Total }} & \multirow{3}{*}{$C c$} & \multirow{3}{*}{ p-value } \\
\hline & \multicolumn{2}{|c|}{ Sesuai } & \multicolumn{2}{|c|}{ Tidak sesuai } & & & & \\
\hline & $\mathbf{N}$ & $\%$ & $\mathbf{n}$ & $\%$ & $\mathbf{N}$ & $\%$ & & \\
\hline Rendah & 12 & 21,4 & 44 & 78,6 & 56 & 100 & \multirow{2}{*}{0,334} & \multirow{2}{*}{0,013} \\
\hline Tinggi & 5 & 71,4 & 2 & 28,6 & 7 & 100 & & \\
\hline
\end{tabular}

Berdasarkan tabel 4 diketahui bahwa dari 56 responden dengan motivasi rendah, sebagian besar tidak sesuai dalam melakukan penempelan program Stiker yaitu sebanyak 44 orang $(78,6 \%)$ sedangkan yang sebanyak 12 orang $(21,4 \%)$. Selanjutnya dari 7 responden dengan motivasi tinggi, sebagian besar sesuai dalam melakukan penempelan Stiker P4K yaitu sebanyak 5 orang $(71,4 \%)$ dan sebagian kecil tidak sesuai sebanyak 2 orang $(28,6 \%)$.

Hasil uji statistik menggunakan chi square diketahui nilai p-value sebesar 0,013, dimana nilai tersebut lebih kecil dari nilai $\alpha 0,05$ yang berarti bahwa terdapat hubungan yang bermakna antara motivasi bidan bidan tentang P4K dengan Penerapan Program Stiker P4K pada Ibu Hamil di Rumah Sakit Imelda Medan nilai contingency coefficient $(\mathrm{cc})=0,334$ berarti bahwa motivasi bidan memiliki keeratan hubungan dalam keeratan rendah dengan penerapan program stiker $\mathrm{P} 4 \mathrm{~K}$.

\subsection{ANALYSIS}

Berdasarkan hasil penelitian diketahui bahwa Hasil distribusi frekuensi diketahui bahwa sebagian besar bidan memiliki motivasi sedang tentang P4K sebanyak 50 responden $(79,4 \%)$, selanjutnya 7 responden (11.1\%) memiliki motivasi tinggi dan 6 responden $(9,5 \%)$ memiliki motivasi rendah Perbedaan tingkat motivasi yang dimiliki oleh bidan pada penelitian ini dapat disebabkan oleh beberapa faktor seperti kompensasi yang diterima dalam penerapan program stiker P4K, beban kerja yang harus dijalankan oleh bidanMotivasi adalah sesuatu yang menimbulkan semangat atau dorongan kerja.

Hasil distribusi frekuensi diketahui bahwa sebagian besar penerapan program stiker P4K tidak sesuai sebanyak 46 orang $(73,0 \%)$ dan sebagian lainnya sesuai dalam penerapan program stiker P4K sebanyak 17 orang $(27,0 \%)$. Penerapan program stiker P4K yang tidak sesuai dapat disebabkan karena jarak rumah ibu hamil dengan tempat pelayanan. Hal ini sesuai dengan yang diungkapkan oleh bidan apabila jarak rumah terlalu jauh dan sulit untuk dijangkau maka penempelan dilaukan sendiri oleh hamil. Hasil penelitian ini didukung oleh penelitian sebelumnya yang dilakukan oleh Dharma yang menyimpulkan bahwa Penerapan P4K dengan stiker belum berjalan sesuai dengan pedoman yang dikeluarkan Departemen Kesehatan.

Pada P4K (Program Perencananaan Persalinan dan Pencegahan Komplikasi) merupakan bentuk kegiatan yang sudah disediakan oleh bidan-bidan di desa bertujuan untuk meningkatkan peran aktif suami, 
keluarga dan masyarakat didalam melakukan perencanaan persalinan yang aman dan siap menghadapi adanya komplikasi bagi ibu hamil termasuk didalamnya program keluarga berencanan (KB) setelah persalinan dengan menfaatkan gambar-gambar sebagai media informasi terhadap sasaran untuk meningkatkan capaian mutu pelayanan kesehatan bagi ibu hamil dan BBL dengan cara meningkatkan peran aktif keluarga keluarga dan masyarakat untuk membuat rencanan persalinan yang aman dan siap mengahdapi komplikasi dan tanda-tanda bahaya persalinan bagi ibu dan melahirkan bayi yang sehat.

Berdasarkan penelitian menunjukkan bahwa ada hubungan antara motivasi bidan tentang P4K dengan Penerapan Program Stiker P4K pada Ibu Hamil di Rumah Sakit Imleda Medan dengan p-value 0,013 $<\alpha=0,05$. Program $\mathrm{P} 4 \mathrm{~K}$ bertujuan meningkatkan capaian mutu pelayanan kesehatan pada ibu hamil dan BBL dengan cara meningkatkan peran aktif keluarga inti dan masyarakat untuk merencanakan kelahiran yang aman serta adanya persiapan mengahdapi komplikasi dan tanda-tanda bahaya persalinan bagi ibu pasca melahirkan bayi yang sehat.

Tabulasi silang antara motivasi bidan tentang $\mathrm{P} 4 \mathrm{~K}$ dengan penerapan program stiker $\mathrm{P} 4 \mathrm{~K}$ menunjukkan bahwa sebanyak 12 responden dengan motivasi rendah tetapi penerapan P4K sesuai, selanjutnya sebanyak 2 orang dengan motivasi tinggi tetapi dengan penerapan stiker P4K tidak sesuai. Hal ini dapat disebabkan oleh jarak rumah yang harus ditempuh bidan untuk melakukan penempelan stiker serta peran serta kader yang masih kurang.

Perbedaan motivasi yang dimiliki oleh bidan berhubungan dengan penerapan program stiker P4K dapat dipengaruhi oleh karakteristik yang dimiliki oleh responden. Hasil distribusi frekuensi berdasarkan data umur diproleh bidan berusia 26-45 tahun (71,4\%). Usia 26-45 tahun merupakan golongan usia dewasa, pada usia ini merupakan usia produktif dimana seseorang memiliki semangat dan energi yang besar untuk mencapai tujuan yang telah direncanakan, tentu berbeda dengan responden yang memiliki usia 17-25 tahun $(6,3 \%)$ dan usia 46-55 tahun $(22,3 \%)$ dimana fungsi tubuh dan semangatnya berbeda dengan usia dewasa.

Berdasarkan pendidikan diketahui sebagian besar dengan pendidikan Diploma III $(81,0 \%)$. Tingkat pendidikan berkaitan dengan kemampuan untuk mencari informasi, mengelola informasi dan kemudian dapat menjadi sebuah tindakan menjelaskan bahwa tingginya pendidikan seseorang semakin mudah dalam mencari sumber informasi serta memiliki kemampuan dalam mengelola informasi tersebut.

(Wibowo, 2010) mengatakan bahwa apabila bidan mempunyi motivasi untuk mencapai tujuannya, setiap bidan harus memaksimalkan bentuk kinerjanya untuk menciptakan kinerja yang maksimal di internal organisasinya. Dengan demikian, meningkatnya motivasi bidan secara individu turut meningkatkan kinerja individu, kelompok, maupun organisasi.

Hasil koefisiensi korelasi (keeratan) hubungan motivasi bidan tentang P4K dengan penerapan program P4K diketahui nilai koefiesnsi korelasi sebesar 0,334 yang berarti termasuk dalam kategori rendah. Berdasarkan data tersebut menunjukan yaitu adanya penerapan program P4K tidak hanya dipengaruhi oleh faktor motivasi tetapi dipengaruhi oleh faktor lain seperti jarak tempat ibu hamil dengan puskesmas atau BPM.

\section{CONCLUSION}

Hasil penelitian menunjukan bahwa Motivasi bidan tentang P4K termasuk dalam kategori motivasi sedang. Penerapan program stiker P4K di Rumah sakit Imelda Medan termasuk kategori tidak sesuai. Terdapat hubungan yang bermakna antara motivasi bidan tentang P4K dengan Penerapan Program Stiker P4K pada Ibu Hamil di Rumah Sakit Imelda Medan dan Keeratan hubungan antara motivasi bidan tentang P4K dengan Penerapan Program Stiker P4K pada Ibu Hamil di Rumah Sakit Imelda Medan termasuk kategori rendah.

\section{REFERENCES}

Anoraga, P. 2006. Psikologi Kerja. Jakarta: Salemba Medika.

Departemen Kesehatan RI. 2009. Pedoman Program Perencanaan Persalinan dan Pencegahan Komplikasi dengan Stiker. Jakarta: Depkes RI.

Dinkes Prov. Sumatera Utara. 2015. Profil Kesehatan Daerah Istimewa Yogyakarta tahun 2012. Sumatera Utara: Dinkes Prov Sumatera Utara.

Dharma, K.K. 2011. Metodologi Penelitian Keperawatan. Jakarta: Trans Info Media.

Dwijayanti, P. 2012. Analisis implementasi Program Perencanaan Persalinan dan Pencegahan Komplikasi (P4K) oleh Bidan Desa di Kabupaten Demak. Jurnal Kesehatan Masyarakat. FKM Universitas Diponegoro.

Notoatmodjo.S. 2010. Metodologi Penelitian Kesehatan. Jakarta: Rineka Cipta.

SDKI. 2012. Laporan Survey Demografi dan Kesehatan Indonesia. Jakarta: Depkes RI.

Sutrisno, E. 2010. Manajemen Sumberdaya Manusia. Jakarta: Kencana. 


\section{BIOGRAPHIES OF AUTHORS}

\begin{tabular}{l|l|} 
& $\begin{array}{l}\text { Khairani, Gelar D-III diperoleh dari Akademi Kebidanan Mitra Husada Medan, } \\
\text { Jurusan Kebidanan pada tahun 2013. Gelar D-IV diperoleh dari Universitas Respati } \\
\text { Yogyakarta, Jurusan Bidan Pendidik Tahun 2014. Magister Kesehatan Masyarakat } \\
\text { diperoleh dari Universitas Respati Indonesia, Jurusan Kesehatan Masyarakat dengan } \\
\text { Konsentrasi Kesehatan Reproduksi pada tahun 2017. Saat ini aktif sebagai dosen tetap } \\
\text { di Prodi DIIIPerekam Dan Informasi Kesehatan Universitas Imelda Medan dan } \\
\text { Sebagai Dosen tetap. }\end{array}$ \\
\hline
\end{tabular}

